\title{
PENGAMANAN OBYEK VITAL NASIONAL DI KAWASAN INDUSTRI BATAMINDO KOTA BATAM
}

\author{
Baru Rochim* \\ PT Sanipak Indonesia
}

\begin{abstract}
Abstrak
Tujuan dari penelitian ini yaitu untuk menganalisis serta mengkritisi penerapan Keppres No. 63 Tahun 2004 tentang Pengamanan Obyek Vital Nasional di Kawasan Industri Batamindo. Disamping itu untuk menganalisis kendala-kendala yang ada dalam proses penerapan pengamanan Obyek Vital Nasional (Obvitnas) di Kawasan Industri Batamindo dan memberikan solusi yang terbaik untuk optimalisasi penerapan Keppres No. 63 Tahun 2004 tentang Obyek Vital Nasional (Obvitnas) di Kawasan Industri Batamindo. Pengumpulan data dilakukan dengan wawancara tidak terstruktur dan observasi, serta penyebaran kuesioner terhadap para HR Manager di Kawasan Industeri Batamindo. Metode Penelitian yang digunakan dalam penulisan ini yaitu pendekatan yuridis sosiologis. Hasil penelitian menunjukkan bahwa komitmen yPengelola Kawasan Industri Batamindo beserta Satuan Pengamanan baik internal maupun POLRI yang ditugaskan dalam rangka Penerapan Keppres No 63 Tahun 2004 Tentang Obyek Vital Nasional di Kawasan Industri Batamindo telah efektif dilaksanakan. Agar hasil yang dicapai terukur maka harus dilakukan sosialisasi secara maksimal pada tataran manajerial dan operasional mengingat produk hukum relatif baru.
\end{abstract}

Kata Kunci : Pengamanan, Obyek Vital, Nasional, Kota Batam

\begin{abstract}
Abstrack
The Objective of this research is to analyze and to criticize the implementation of Presidential Decree No. 63:2004 On National Vital Assets in Batamindo Industrial Park. In addition, it is to analyze what barriers process are found during its implementation, and to offer the best possible solutions to it in order to maximize the implementation of Presidential Decree No. 63:2004. The research was collected from interviews, observations \& questioners to the HR Managers in Batamindo Industrial Park. The research was done by using Socio-legal approach. The research result shows that the commitmenst from the Batamindo Industrial Park caretaker, Internal Security and State Police that are in charge for the National Asset security based on Presidential Decree No. 63:2004 on National Assets have been well implemented. To have a measurable result, a socialization to managerial and operational level is highly needed since the Law is relatively new.
\end{abstract}

Key Words: Security, Vital Object, National,Batam city

*Alamat Korespondensi : baru.rochim@tunaskaryaindoswasta.com 


\section{A. Latar Belakang Masalah}

Dengan adanya kawasan-kawasan dan atau tempat wisata, rumah sakit dan bandara atau pelabuhan berpotensi adanya ancaman yang dapat menghambat dan bahkan dapat merugikan negara serta kerugiannya dapat mengganggu stabilitas ekonomi dan politik negara maka Presiden mengeluarkan Keputusan Presiden Nomor 63 Tahun 2004 Tentang Pengamanan Obyek Vital sebagaimana pada pasal 1 ayat 4 yang berbunyi Ancaman adalah setiap usaha dan kegiatan dengan segala bentuknya baik yang berasal dari dalam negeri maupun luar negeri yang dinilai dapat berpotensi membahayakan kelangsungan berfungsinya Obyek Vital Nasional. Peneliti bertujuan untuk meneliti penerapan Keppress diatas di Kawasan Industeri Batamindo dimana telah mendapatkan sertifikat Obyek Vital Nasional pada tanggal 2 September 2014 untuk diketahui data yang dapat dikumpulkan dari berbagai sumber dintaranya adalah responden dari anggota IPSM Kepri (Ikatan Praktisi Sumber Daya Manusia-Kepri) wadah dari para Human Resourch /personalai adalah sebagaimana berikut dibawah :

Daftar Perusahaan yang berlokasi di Kawasan Industri Batamindo yang mempunyai kasus hubungan Industrial ${ }^{1}$ serta masalah internal dalam perusahaan yang sebagian besar disertai aksi unjuk rasa, demontrasi dan mogok kerja pada periode tahun 2004 - 2015 terdapat 34 perusahaan ( kurun waktu dimana sebelum diterbitkannya Keppres No 63 Tahun 2014 Tentang Pengamanan Obyek Vital Nasional sampai dengan diterbitkannya Keppres tersebut maka tergambar pada grafik dibawah ini), untuk diketahui bahwa Kawasan Industri Batamindo telah mendapatkan sertifikate Obvitnas (obyek vital nasional) pada tanggal 2 September 2014.

Grafik A.1.2

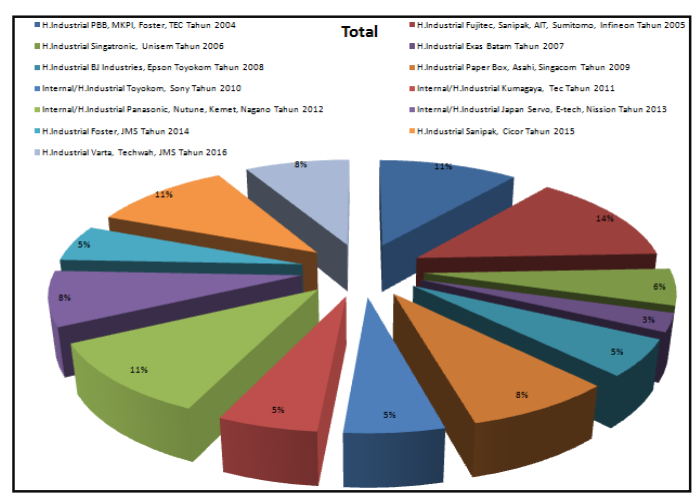

1 . Pasal 1 : Undang-undang No 2 Tahun 2004 Tentang Penyelesaian Hubungan Industrial.

${ }^{2}$ Data table disusun berdasarkan keterangan para senior HR yang pernah bekerja di perusahaan sebagai HR Manager pada parusahaan yang masuk dalam daftar table diatas ditambah dengan data yang diambil pada dokumen IPSM - Kepri. 
Pasca reformasi hingga terbitnya Keppres No 63, hubungan industrial di Kawasan Industri Batamindo mengalami naik turun namun berdasarkan data diatas kejadian demontrasi, unjuk rasa serta mogok menjadi salah satu foktor adanya relokasi dan tutupnya sebagian dari perusahaan yang berada di kawasan tersebut, terkait dengan penerapan Keppres 63 tentu menjadi harapan akan adanya kepastian hukum serta kemudahan dalam berinvestasi disamping membuat nyaman dan aman para investor saat ini masih bertahan. Terkait dengan Dassollen sebenarnya sangat jelas bagaimana ketika terjadi adanya pemasalahan hubungan industial maka telah diatur sesuai dengan per undang-undangan yang ada mulai dari Undang-Undang Dasar Negara Republik Indonesia Tahun 1945, terutama pada pasal 3 ayat $28 .{ }^{3}$ kemudian juga Undang-Undang Republik Indonesia Nomor 3 Tahun 2013 tentang Ketenagakerjaan pasal $137 .{ }^{4}$ Sedangkan pasal 138 ayat $1{ }^{5}$ dan ayat $2 .{ }^{6}$ serta Undang - undang Republik Indonesia Nomor 2 Tahun 2004 Tentang Penyelesaian Perselisihan Hubungan Industrial kaitannya dengan judul maka dapat dilihat dari pasal 3 ayat 1 sampai dengan ayat 3. ${ }^{7}$ ditambah lagi dengan adanya undang - undang Republik Indonesia Nomor 2 Tahun 2004 Tentang Penyelesaian Perselisihan Hubungan Industrial pada pasal 3,4 serta Undang - Undang Republik Indonesia Nomor 9 Tahun 1998 Tentang Kemerdekaan Menyampaikan Pendapat di Muka Umum. $^{8}$ Namun kenyataannya dilapangan ( Das Sein) bahwa peraturan perundangundangan diatas seakan tidak berfungsi di Kawasan Industri Batamindo sehingga pelanggaran hukum terjadi dalam Kawasan Industri, hal ini terlihat dalam data grafik

3 Pasal 3 ayat 28 UUD 1945 "Setiap orang berhak atas kebebasan berserikat, berkumpul dan mengeluarkan pendapat"

${ }^{4}$ Mogok kerja sebagai hak dasar pekerja/buruh dan serikat pekerja/serikat buruh dilakukan secara sah, tertib, dan damai sebagai akibat gagalnya perundingan" sedangkan pada pasal 138 ayat 1 berbunyi " Pekerja/buruh dan/atau serikat pekerja/serikat buruh yang bermaksud mengajak pekerja/buruh lain untuk mogok kerja pada saat mogok kerja berlangsung dilakukan dengan tidak melanggar hukum

${ }^{5}$ Pekerja/buruh dan/atau serikat pekerja/serikat buruh yang bermaksud mengajak pekerja/buruh lain untuk mogok kerja pada saat mogok kerja berlangsung dilakukan dengan tidak melanggar hukum

${ }^{6}$ Pekerja/buruh yang diajak mogok kerja sebagaimana dimaksud pada ayat(1), dapat memenuhi atau tidak memenuhi ajakan tersebut.

7 (1)Perselisihan hubungan industrial wajib diupayakan penyelesaiannya terlebih dahulu melalui perundingan bipartit secara musyawarah untuk mencapai mufakat. (2) Penyelesaian perselisihan melalui bipartit sebagaimana dimaksud dalam ayat (1) harus diselesaikan paling lama 30 (tiga puluh) hari kerja sejak tanggal dimulainya perundingan. (3) Apabila dalam jangka waktu 30 (tiga puluh) hari sebagaimana dimaksud dalam ayat (2) salah satu pihak menolak untuk berunding atau telah dilakukan perundingan tetapi tidak mencapai kesepakatan, maka perundingan bipartit dianggap gagal.

8 Penyampaian pendapat di muka umum sebagaimana dimaksud dalam ayat (1). dilaksanakan di tempattempat terbuka untuk umum. kecuali : a. di lingkungan istana kepresidenan, tempat ibadah. instalasi militer, rumah sakit, pelabuhan udara atau laut, stasiun kereta api. terminal angkutan darat, dan obyekobyek vital nasional ; b. pada hari besar nasional. 
diatas yang menunjukkan eskalasi terjadinya demontrasi/unjuk rasa dan mogok sehingga berakibat adanya hambatan kelangsungan produksi serta berakibat adanya relokasi dan tutupnya sebagian perusahaan, dengan adanya Keppres 63 merupakan satu harapan bagi para pihak untuk dapat dijadikan landasan penegakan hukum di Kawasan Industri agar dampak dari gerakan yang dapan mengancam dan menghambat proses produksi serta usaha perusahaan dapat diminimalisir disamping adanya pemusatan perhatian keamanan oleh aparat dan pemerintah juga masyarakat bagi kawasan yang telah mendapatkan sertifikasi Obyek Vital Nasioanal seperti Kawasan Industri Batamindo.

\section{B. Permasalahan Penelitian}

Berdasarkan uraian latar belakang penelitian diatas, maka permasalahan dalam penelitian ${ }^{9}$ ini dirumuskan sebagai berikut :

1. Apakah penerapan Keppres No. 63 Tahun 2004 tentang Pengamanan Obyek Vital Nasional di Kawasan Industri Batamindo sudah efektif diterapkan?

2. Kendala-kendala apa saja dalam proses penerapan pengamanan Obyek Vital Nasional (Obvitnas) di Kawasan Industri Batamindo?

3. Bagaimana solusi yang terbaik untuk optimalisasi penerapan Keppres No. 63 Tahun 2004 tentang Obyek Vital Nasional (Obvitnas) di Kawasan Industri Batamindo?

\section{Metode Penelitian}

Penelitian yang ditujukan untuk menganalisis permasalahan yang dirumuskan diatas, dilakukan dengan metode pendekatan Yuridis Sosiologis. Yuridis Sosiologis adalah penelitian hukum yang menggunakan data sekunder sebagai data awalnya, yang kemudian dilanjutkan dengan data primer atau data lapangan, meneliti efektivitas suatu Undang-Undang dan penelitian yang ingin mencari hubungan (korelasi) antara berbagai gejala atau variabel sebagai alat pengumpul datanya terdiri dari studi dokumen, pengamatan (observasi), dan wawancara (interview), pengumpulan kuesioner ${ }^{10}$.

Untuk menjawab permasalahan dalam penelitian ini, peneliti melakukan beberapa tahap penelitian, pertama Penelitian lapangan dimana masih adanya unjuk rasa/demontrasi yang dilakukan oleh serikat pekerja/buruh di Kawasan Industri Batamindo dan kedua Penelitian tentang perundang-undangan yang berkaitan dengan pengamanan Obyek Vital Nasional, sedangkan Objek Penelitian ini adalah penelitian hukum sosiologis, maka data yang digunakan adalah data primer dan sekunder. Data primer diperoleh dari hasil wawancara dan observasi juga pengumpulan kuesioner sedangkan data sekunder diperoleh dari bahan-bahan hukum

\footnotetext{
9. Soejono Soekanto, Pengantar Penelitian Hukuam (Jakarta UI-Press), 2014 hal 3.

10. Amiruddin, Pengantar Metode Penelitian Hukum, Jakarta: PT. Raja Grafindo Persada, 2012, Hal. 34
} 
primer dan sekunder, yaitu ${ }^{11}$. Untuk mengetahui Data Primer, adalah data yang diperoleh secara langsung dari sumbernya, yang dalam hal ini diperoleh dengan wawancara dan pengumpulan kuesioner terhadap Personalia Perusahaan pada perusahaan di Kawasan Industri Batamindo, Personalia perusahaan. Adapun pengambilan sampel terhadap orang-orang yang diwawancarai adalah dengan teknik purposive sampling yaitu pengambilan sampel secara sengaja sesuai dengan persyaratan sampel yang diperlukan. Dalam bahasa sederhana purposive sampling itu dapat dikatakan sebagai secara sengaja mengambil sampel tertentu (orang-orang tertentu) sesuai persyaratan (sifat-sifat, karakteristik, ciri, kriteria) sampel.

Dalam hal ini orang-orang tertentu yang dijadikan sample adalah merupakan para pelaku kunci dalam perusahaan di Kawasan Industri Batamindo. Perusahaan yang berada di Kawasan Industri Batamindo, sehubungan penelitian ini adalah penelitian hukum sosiologis, maka data yang digunakan adalah data primer dan sekunder. Data Sekunder, yaitu data yang mendukung keterangan atau menunjang kelengkapan data primer, dengan mempelajari data sekunder yang berupa bahan-bahan pustaka, peraturan, ketentuan-ketentuan hukum yang berhubungan dengan permasalahan dan/atau yang diteliti. Sedangkan Data Sekunder adalah sebagaimana berikut :

\section{a. Bahan Hukum Primer}

Bahan hukum primer, adalah bahan-bahan hukum yang mengikat yang terdiri dari peraturan perundang-undangan yang relevan denganpermasalahan. Bahan hukum primer dalam penelitian ini berasal dari peraturan perundang-undangan yang berkaitan dengan penelitian hukum yang dilakukan, yaitu :

- Undang-Undang Dasar Negara Republik Indonesia 1945

- Undang-Undang No. 2 tahun 2014 tentang Kepolisian Negara Republik Indonesia

- Undang - Undang No 3 tahun 2013 tentang Ketenagakerjaan

- Undang-Undang Republik Indonesia Nomor 2 Tahun 2004 Tentang Penyelesaian Perselisihan Hubungan Industrial.

- Undang - Undang Republik Indonesia Nomor 9 Tahun 1998 Tentang Kemerdekaan Menyampaikan Pendapat di Muka Umum.

- Keputusan Presiden Nomor 63 tahun 2004 tentang Pengamanan Obyek Vital Nasional.

\section{b. Bahan Hukum Sekunder}

Bahan hukum sekunder, adalah bahan-bahan yang memberikan penjelasan mengenai bahan hukum primer. Bahan hukum sekunder dalam penelitian ini berupa buku-buku, makalah, majalah, jurnal, laporan hasil penelitian, dan karya ilmiah lainnya yang berhubungan dengan obyek penelitian.

\section{c. Bahan Hukum Tersier}

Bahan hukum tersier adalah bahan hukum yang memberikan informasi dan penjelasan terhadap bahan hukum primer dan sekunder, meliputi: Kamus Hukum,

${ }^{11}$. Soerjono Soekanto,Pengantar Penelitian Hukum, Jakarta: Rajawali Pers, 1996, Hal. 52 
Kamus Besar Bahasa Indonesia (KBBI), Kamus Bahasa Inggris, Ensikopedia, dan lain-lain.

Untuk Teknik Pengumpulan Data yang diperlukan dalam penelitian ini disesuaikan dengan metode pendekatan dan jenis data yang digunakan. Maka teknik pengumpulan data yang digunakan adalah dengan wawancara menggunakan tanya jawab langsung yang ditujukan langsung kepada pihak-pihak yang berhubungan. Wawancara dilakukan dengan beberapa narasumber yaitu CSO PT BIC (chief security operational PT BIC), Pengurus Serikat Pekerja, Pengurus IPSM Kepri ( organisasi wadah para praktisi SDM/HR se Kepri), Perwira Polisi yang ditugaskan sebagai Pawas Pam Obvit di Kawasan Industri Batamindo terkait dengan maksud menguatkan data dan memperoleh informasi yang lebih mendalam mengenai permasalahan yang ada. Kemudian dilakukan dengan Pengamatan (Observasi) ${ }^{12}$ langsung pada lokasi di Kawasan Industri Batamindo sebelum dan sesudah Pengamanan Obyek Vital Nasional di terapkan dalam Kawasan Industri Batamindo. Kemudian juga melalui Studi Dokumen, Peneliti melakukan studi dokumen terhadap buku-buku dan literaturliteratur yang berhubungan dengan penelitian ini untuk memperoleh landasan teoritis yang dapat digunakan untuk menganalisis Penerapan Pengamanan Obyek Vital Nasional di Kawasan Industri Batamindo dan yang terakhir adalah dengan Penyebaran Kuesioner kepada para HR atau personalia perusahaan representative dari Kawasan Industri Batamindo dengan pertanyaan-pertanyaan terkait seputar dengan penelitian untuk selanjutnya di analisis berdasarkan teori yang akan digunakan.

Untuk Metode Analisis Data Didalam menganalisa data pada penelitian ini, peneliti menggunakan metode pendekatan yuridis kualitatif yaitu ${ }^{13}$ metode penelitian dengan data fenomena, fokus yang hanya bisa dijelaskan secara naratif dan tidak bisa dibuktikan dengan pengukuran. ${ }^{14}$ Didalam menganalisa data pada penelitian ini berangkat dari penelitian yuridis sosiologis dengan penelitian terhadap berlakunya hukum, atau terkait dengan efektivitas, dampak serta identifikasi persoalan hukum Penerapan Keppres No. 63 Di Kawasan Industri Batamindo dan aspek -aspek permasalahan didalam latar belakang permasalahan yang diajukan dalam penelitian ini, maka yang dilakukan peneliti adalah analisis kualitatif. Sedangkan teknik pengumpulan data berupa pengamatan, kuesioner dan wawancara. Sebagimana didalam Joko Subagyo dikatakan ${ }^{15}$. Didalam menganalisis bahan primer sosiologis yuridis, dengan analisis kualitatif terhadap bahan-bahan yang diajukan peneliti juga menggunakan beberapa penafsiran atau interpretasi analisis yuridis antara lain Interpretasi Subsumtif ${ }^{16}$ yaitu metode penafsiran dengan menerapkan suatu teks terhadap kasus in concreto, dengan menerapkan sillogisme adalah bentuk berfikir logis

12. Soerdjono,Soekanto, Loc.cit

13. Rina S. Shahrullah, Penelitian Kualitaif, Bahan Kuliah Metodologi Penelitian Hukum, tidak diterbitkan, Magister Hukum Universitas Internasional Batam Batch 8, 2015 hal. 2.

14 Ibid.

15 P. Joko,Subagyo, Metode Penelitian Dalam Teori dan Praktek, Rineka Cipta, Jakarta : 1997, hal.106.

16 Bambang,Sutiyoso, Metode Penemuan Hukum, Upaya Mewujudkan Hukum Yang Pasti dan Berkeadilan, UII Press, Yogyakarta: 2006, hal. 80. 
dengan mengambil kesimpulan dari hal-hal yang bersifat umum (premis mayor atau peraturan perundang-undangan) dan hal-hal yang bersifat khusus (premis minor atau peristiwanya). Interpretasi sistematis $(\operatorname{logis})^{17}$ yaitu suatu metode menafsirkan peraturan perundang-undangan dengan menghubungkannya dengan peraturan hukum (undang-undang lain) atau dengan keseluruhan sistem hukum.Dalam penelitian ini, Tahapan dalam menganalisis bahan hukum dilakukan melalui mekanisme deengan tahapan pertama adalah dengan pengkategorian bahan hukum selanjutnya tahapan kedua melakukan penyajian bahan hukum dalam beberapa tabel berdasarkan kelompok responden antara lain; fungsi kewenangan, hubungan sistem keamanan dalam perusahaan, fungsi hubungan kerjasama para pihak terkait, serta aturan perundang-undangan yang mengatur dengan penerapan pengamanan Obyek Vital Nasional (OBVITNAS) dan persoalan yang melingkupinya sebagaimana tujuan penelitian ini sedangkan tahapan ketiga adalah analisis bahan hukum, dalam tahapan ini peneliti akan menganalisis bahan-bahan hukum yang telah dikumpulkan. Seluruh bahan tersebut di deskripsikan dengan analisis yuridis sosiologis dengan peneliti akan lebih mempertajam analisis normatif pengamanan mengenai efektifitas, keberlakuan, fungsi dari pada ketentuan aturan dan faktor ketaatan dan ketertiban terhadap ketentuan aturan yang berlaku mengaturnya, dan kemudian untuk mengkaji faktorfaktor yang menyebabkan tidak efektifnya ketentuan peraturan tersebut didalam mengatur dan menerapkan fungsi hukum pengamanan didalam persoalan penerapan pengamanan obyek vital nasional di Kawasan Industeri Batamindo dan tahapan terakhir yang akan dilakukan oleh peneliti adalah penarikan kesimpulan, dalam langkah ini, semua data-data yang telah dianalisis akan diambil kesimpulan, dan merupakan jawaban dari permasalahan penelitian ini.

\section{Hasil Penelitian dan Pembahasan}

Sudah menjadi kebutuhan setiap individu akan rasa aman. Menurut hierarchy of needs dari Maslow, Keamanan atau sekuriti (security) termasuk didalam kebutuhan dasar yang kedua setelah kebutuhan-kebutuhan biologis dan sisiologis, yaitu Safety needs. Di dalam kebutuhan akan rasa aman dan perlindungan dari hal-hal yang dianggap sebuah ancaman. Kebutuhan terhadap sekuriti ini tidak hanya dibutuhkan oleh setiap individual, namun juga dibutuhkan oleh kelompok-kelompok, golongan, serta dunia industri. Didalam dunia industri kebutuhan sekuriti ini merupakan hal yang mutlak diperlukan untuk melindungi ase-aset dari usahanya yang terdiri dari sumber daya manusia, peralatan, maupun proses produksi dari usaha industri itu sendiri. Pengamanan yang diperlukan yaitu pengamanan fisik (gedung, mesin,peralatan, proses produksi), pengamanan personil (pekerja), serta pengamanan informasi (rahasia, data kebijakan perusahaan). Konsep dalam penerapan pengamanan kawasan industri yang nota bene mempunyai pengertian berbeda dengan penerapan pengamanan di area lainnya karena kawasan industri merupakan lokasi dengan batasbatas tertentu dan mempunyai spesifikasi tertentu untuk itu penerapan pengamanan harus mempunyai cara yang dapat diterapkan sebagaimana berikut : pertama adalah

17 Ibid, hal. 82. 
Konsep Management, untuk mendukung keamanan dan kenyamanan suatu kawasan yang nyaman dan mapan yang juga harus didukung oleh berbagai sarana dan prasarana yang baik, dan yang tidak kalah penting yaitu adanya sistem keamanan dan managemen yang baik, guna mendukung keberhasilan suatu perusahaan atau perindustrian sehingga terhindar dari ancaman, gangguan yang dapat merugikan baik terhadap kegiatan operasional dan sarana prasarana yang ada. Konsep Manajemen dan sistem keamanan mutlak diperlukan dan harus ada dalam membangun dan mengoperasionalkan baik itu menyangkut pelaksanaan kegiatan rutin manajemen perusahaan atau perindustrian serta upaya peningkatan keamanan dengan membuat dan merencanakan strategi penanganan yang cepat, tepat dan efektif, antara lain terhadap peningkatan dan pengembangan sumber daya manusia serta melengkapi sarana dan prasarana untuk mengatasi dan mencegah terjadinya berbagai macam bentuk gangguan keamanan yang dapat menghambat proses keberlangsungan produksi dan managerial operasional dalam industri tersebut. Salah satu upaya yang efektif antara lain dengan memanfaatkan potensi satuan keamanan (satpam). Akan tetapi dalam pengamanan Obyek Vital Nasional (OBVITNAS) satpam tidak termasuk didalamnya hanya sebagai pendukung didalam operasionalnya ${ }^{18}$.

Kedua adalah Konsep Sekuriti Fisik Konsep sekuriti fisik dari beberapa tinjauan pustaka pemahamannya adalah kegiatan keamanan yang ditujukan kepada fisik untuk mencegah terjadinya ancaman dan kerugian. Diantara tinjauan pustaka sekuriti berikut: Hadiman (2009) ${ }^{19}$ mengatakan bahwa sekuriti fisik adalah segala usaha atau kegiatan pengamanan yang ditujukan untuk mencegah ancaman, bahaya atau bencana baik yang disebabkan oleh manusia, alam maupun binatang. Awaloedin Djamin (2012:9) ${ }^{20}$ menyatakan bahwa ruang lingkup dari industrial security meliputi beberapa bagian besar diantaranya adalah Physical Security (sekuriti fisik), yaitu pengamanan fisik asset organisasi perusahaan, instansi dan lain-lain. Pengamanan fisik meliputi pengamanan gedung dan lingkungan, pintu gerbang, pagar, kunci-kunci, CCTV, metal detektor, jendela dan lain-lain, serta jumlah dan klasifikasi jumlah Satpam. Termasuk juga pencegahan dari bencana, alarm kebakaran, keselamatan, prosedur penyelamatan dan lain sebagainya peralatan yang diperlukan dalam lingkup sekuriti fisik. Personnel Security (sekuriti personil), secara umum personil sekuriti berarti pengamanan terhadap seluruh pegawai/pekerja didalam organisasi. Pada pelaksanaannya dapat dipisahkan sebagai; Pertama, melindungi pimpinan perusahaan dari gangguan keamanan dan keselamatan seperti executive protection dan body guards. Kedua,melindungi organisasi dari kejahatan yang dilakukan oleh pegawai yang tidak jujur seperti internal theft dan petit corruption. Information Security (sekuriti informasi), adalah pengamanan semua informasi perusahaan /organisasi yang tidak boleh diketahui oleh pihak luar, baik berupa informasi lisan (rapat, pembicaraan telepon), informasi tulisan (dokumen-dokumen) ataupun yang berupa simbolsimbol (symbolistic), saat ini seiring dengan kemajuan teknologi informasi seperti komputer dan lain sebagainya ${ }^{21}$.Ketiga adalah Akses Kontrol Pencegahan untuk akses kontrol

18. Muhammad Anwar, CSO PT BIC, replay SMS tanggal 03 Juli 2016 pukul 10.49

19 Hadiman,H.Sekuriti Fisik

${ }^{20}$. Wikipedia, Awaloedin Djamin tokoh Kepolisian Republik Indonesia, https://id.wikipedia.org

${ }^{21}$ Awaloedin Djamin atau Bapak Satpam Indonesia. 
dalam pengamanan sangat penting dimaksudkan untuk usaha mencegah pihak-pihak yang tidak berhak agar tidak memasuki / menggunakan sumberdaya komputer dan juga melindunginya dari gangguan dan ancaman yang dapat mengganggu stabilitas keamanan. Hal-hal yang termasuk kategori pencegahannya adalah seperti Back-up file/dokumentasi: yaitu untuk mencegah agar bila terjadi kecelakaan terhadap sistem komputer, file/dokumen penting tetap ada. Dokumen back-up ini sebaiknya disimpan ditempat yang berjauhan dan dengan perlakuan keamanan yang setara dengan dokumen aktifnya. Pemagaran: yaitu untuk membatasi agar hanya orang-orang yang berhak saja yang dapat memasuki sistem. Termasuk dalam sistem pemagaran adalah CCTV, alarm, anjing penjaga dan pagar. Pos keamanan: pos keamanan adalah tempat penjaga keamanan yang difungsikan untuk penjaga keamanan menyeleksi keluar masuk orang,kendaraan dan lainnya yang berpotensi mengancam area yang dijaganya. Penjaga keamanan: pada intinya hampir sama dengan pemagaran namun dengan keunggulan dapat melihat hal-hal yang berkenaan dengan bawaan personel yang akan memasuki area sistem. Agar lebih efektif perlu ditunjang dengan alat-alat elektronik seperti detektor. Sistem tanda pengenal: yaitu untuk mengenali bahwa orang tersebut adalah pihak yang memang diberikan akses tertentu. Sistem pintu ganda: biasanya digunakan untuk membedakan level keamanan dalam sebuah sistem. Umumnya pintu 1 adalah area aman dan pintu 2 adalah area terbatas. Kunci: yang dimaksud adalah kunci (yang terbuat dari) metal dan kunci kriptografi. Back-up power: yaitu untuk memastikan tidak ada pemutusan power/listrik secara mendadak yang akan mengakibatkan kerusakan pada sistem. Back-up power biasanya berupa baterai cadangan atau generator diesel. Perangkat yang paling populer adalah ups (uninterruptible power supply). Access Control biometrik : fungsinya hampir sama dengan sistem tanda pengenal, namun menjadi lebih baik karena biometrik menempel pada tubuh, sehingga kecil kemungkinannya untuk hilang atau terlupakan. Access control biometrik ini sangat baik digunakan untuk level keamanan tinggi namun dengan pemakaian akses yang jarang. Pemilihan lokasi: adalah faktor yang sangat penting untuk menghindari resiko yang mungkin timbul akibat bencana banjir, kebakaran, radiasi gelombang elektromagnetik atau yang lainnya. Pemadam kebakaran: kebakaran akan merusak sistem. Selain lokasi sistem harus jauh dari tempat yang menjadi pemicu kebakaran, material yang digunakan pun sebaiknya yang tidak mudah terbakar. Alat pemadam kebakaran perlu diletakkan ditempat yang tepat dan mudah dijangkau dengan bahan yang baik, sebab bahan pemadam yang buruk akan merusak sistem bagaikan api itu sendiri. Kempat adalah Metode Pengamanan Metode pengamanan Metode pengamanan yang digunakan dalam upaya mengamankan lokasi atau area yang menjadi obyek pengamanan biasanya dengan metode: a. Monitoring system (CCTV) Merupakan upaya pengamanan yang dilakukan dengan menggunakan sistim pengamanan electronic yang berupa CCTV yang diletakkan dibagian dalam perusahaan, pada tempat-tempat strategis yang dinilai rawan terhadap kemungkinan terjadinya suatu pelanggaran dan dapat memantau secara umum situasi di dalam dan kawasan industri perusahaan. b. Sensor Magnetik Sensor magnetik merupakan alat deteksi (detektor), yang diletakkan pada suatu barang, yang akan aktif apabila seseorang masuk dalam kawasan industri Perusahaan, karena terdapat alat pendeteksi di pada pintu/gerbang masuk kantor dan gedung. c. 
Pengamanan umum yang dilakukan oleh PT. BIC selaku Pengelola Kawasan, dengan membangun sarana pengamanan secara umum, berupa: Pos Polisi, Pemagaran kawasan industri perusahaan untuk melindungi dari gangguan yang mungkin timbul dari luar wilayah kawasan perusahaan. d. Pengamanan khusus

Untuk bagaimana penyelenggara pengamanan maka PT. BIC semenjak mendapatkan sertifikasi Obyek Vital Nasional maka sudah stand by Pam Obvit Merujuk pada Perkap nomor 22 Tahun 2010 tentang susunan organisasi dan tata kerja pada tingkat kepolisian daerah tersebut diataranya adalah bertugas menyelenggarakan kegiatan pengamanan terhadap obyek khusus yang melipui personel dan fasilitas, meateriil logistik, kegiatan di dalam fasilitas lembaga negara perwakilan negara asing, lingkungan industri termasuk VIP dan obyek pariwisata yang memerlukan pengamanan khusus. Disamping itu mempunyai Fungsi Pembinaan manajemen operasional dan pelatihan, penyelenggaraan serta pengumpulan dan pengolahan data serta penyajian informasi dan dokumentasi program kegiatan Ditpamobvit: Pengamanan lingkungan industri dan kawasan tertentu yang memerlukan pengamanan khusus; Pengamanan obyek wisata termasuk mobilitas wisatawan yang memerlukan pengamanan khusus; Pengamanan kementerian dan lembaga negara termasuk VIP, yang memerlukan pengamanan khusus; dan Pengamanan perwakilan negara asing termasuk VIP, yang memerlukan pengamanan khusus, sedangkan Sistem dan Prosedur Pengamanan ${ }^{22}$ Bertolak dari kondisi dan situasi serta luas area yang ada dimasing-masing kantor di lingkungan perusahaan Kawasan Industri Batamindo, maka sistem dan prosedur pengamanan yang ditetapkan / difokuskan untuk dapat mengantisipasi berbagai macam gangguan yang mungkin timbul guna melindungi Personil, Materiil / asset, dokumen penting untuk teritorial dan kebijaksanaan.Terkait dengan berbagai instrumen dan infrastruktur diatasa sangat memadai dan dapat menunjang status Kawasan Industri Batamindo menjadi status OVNI (Obyek Vital Nasional) namun apakah status tersebut benar-benar telah dapat menjawab persoalan selama ini, menurut Deny Fery Silalahi, $\mathrm{SH}^{23}$ status Obvitnas diatas seperti dipaksakan karena proses pengajuannya tanpa adanya sosialisasi walaupun keberadaanya yang bersangkutan setuju karena mempunyai dampak yang baik kepada para pihak, namun masih dipelukannya sosialisasi kepada para stakeholder di Kawasan Industri Batamindo. Menurut Syaiful Badri Sofyan, $\mathrm{SH}^{24}$, disamping faktor pengamanan diperlukan adanya saling koordinasi dan komukasi antar stakeholder di Kawasan industri Batamindo agar dicapai hasil yang bai, selama ini sudah baik dengan adanya HR forum dan Union forum terkait dengan pengamanan obyek vital nasional sangat diperlukan agar supaya ada kepastian hukum. Menurut Richard Rando Sidabutar, $\mathrm{SH},{ }^{25}$ penerapan pengamanan obyek vital nasional di kawasan industri

\footnotetext{
${ }^{22}$ Chief Security Operation PT BIC, Standard Operational Prosedur Pengamanan di Kawasan OBVITNAS di

Kawasan Industri Batamindo Muka Kuning

${ }^{23}$ Deny Fery Silalahi, SH, adalah Direktur LBH SPMI Kota Batam, wawancara dilakukan Rabu 27 Juli 2016, Pukul 11.30 WIB.

${ }^{24}$ Syaiful Badri Sofyan, SH, adalah Ketua Serikat Pekrja Seluruh Indonesia (KSPSI) Kota Batam, wawancara dilakukan Kamis 28 Juli 2016 Pukul 11.00 WIB.

${ }^{25}$ Rihard Rando Sidabutar, SH, Ketua Divisi Hukum Korwil KSBSI Kepri, wawancara dilakukan Jumat 29 Juli 2016, Pukul 10:45.
} 
Batamindo merupakan langkah yang baik namun jangan sampai mengurangi hak-hak buruh untu melakukan demontrasi/unjukrasa sepanjang mereka telah mengikuti kententuan perundang-undangan. Menurut Arnold Dharmawan Arsad, $\mathrm{SH},{ }^{26}$ standart pengamanan kawasan industri Batamindo setelah mendapatkan sertifikate atau status OBVITNAS sudah cukup memadai dan penerapanya Keppres 63 juga telah baik namun untuk menjadi lebih baik dapat mengadakan pertemuan-pertemuan para pihak dan yang telah dilakukan saat ini kiranya dapat dipertahankaan. Menurut Budi Purnomo ${ }^{27}$ setelah diterapkannya keppres 63 dan terkait dengan telah berstatusnya obyek vital nasional kawasan industri Batamindo sudah relative terarah walaupun masih ada beberapa kejadian unjuk rasa atau demo namun dari kuantitas menurun hal ini menunjukkan adanya keefektifan Keppres diatas. Sedangkan menurut AKBP Nugraha Dwi Prianto SIK, ${ }^{28}$ Keppres 63 tentang pengamanan obyek vital nasional dan terkait dengan telah berstatusnya obyek vital nasional kawasan industri Batamindo berjalan dengan baik walaupun demikian masih diperlukan adanya sosialisasi berkelanjutan untuk menyamakan persepsi dengan para stakeholder serta satuan pengaman itu sendiri. Menurut Tjau Hioeng ${ }^{29}$ terkait dengan penerapan pengamanan obyek vital nasional di kawasan industri Batamindo sejak telah ditetapkannya kawasan ini menjadi OVNI pada tanggal 2 September 2014 mempunyai perkembangan yang baik dalam hal unjuk rasa atau demontrasi di kawasan industri Batamindo dari pihak pengaman telah malakukan tugas dengan baik walaupun masih diperlukan sosialisasi tentang obyek vital nasional secara kontinue agar persepsi tentang definisi definisi yang ada pada Keppres dipahami bersama maka sosialisasi tetap dilakukan secara continue walaupun penerapan keamanan saat ini sudah efektif. Selanjutnya menurut Adhy P Wibowo ${ }^{30}$ semua prosedur terkait dengan penerapan Keppres 63 tentang pengamanan obyek vital nasional di Kawasan Industeri Batamindo telah dilakukan sesuai dengan ketentuan SOP yang dijadikan standard, kordinasi dan komunikasi pengamanan internal dilakukan setiap saat sehingga bila terjadi kerawanan cepat untuk diselesaikan, prosedur dan mekanisme pengamnan sesuai dengan SOP yang ada namun sosialisasi tetap diperlukan agar keseragaman dalam pandangan penerapan pengamanan menjadi lebih baik dari sekarang. Sementara hasil daripada observasi tergambar adanya pergeseran kuantitas dari gerakan aksi unjuk rasa dan demontrasi di Kawasan Industri Batamindo dari sebelum dikeluarkanya Keppres 63/2004 dan sesudah diterbitkanya Keppres diatas, data menunjukkan sebagaimana terlampir dibawah :

\footnotetext{
${ }^{26}$ Arnold Dharmawan Arsad, SH, Koordinator Advokasi Ikatan Praktisi Sumber Daya Manusia-Kepri (IPSM-KEPRI).

${ }^{27}$ Budi Purnomo, Chief Security PT BIC, wawancar dilakukan Senin 8 Agustus 2016, Pukul 17.00

${ }^{28}$ AKBP Nugraha Dwi Prianto SIK, Kepala Bagian Pembinaan Operasional Direktorat pengamanan Obyek Vital Polda Kepri, wawancara dilakukan Selasa 2 Agustus 2016, pukul 11;00

${ }^{29}$. Tjau Hioung Manager Admin \& General Affair PT BIC, wawancara dilakukan pada Rabu tanggal 8 Agustus 2016 pukul 16:15.

30. Adhy P Wibowo Legal PT BIC, wawancara dilakukan Jumat tanggal 8 Agustus 2016, Pukul 09:57 WIB.
} 
A. Daftar Perusahaan yang mempunyai kasus hubungan Industrial ${ }^{31}$ serta masalah internal dalam perusahaan yang sebagian besar disertai aksi unjuk rasa, demontrasi dan mogok kerja pada periode tahun 2004 $-2015$

\begin{tabular}{|c|c|c|c|c|}
\hline NO. & $\begin{array}{l}\text { NAMA } \\
\text { PERUSAHAAN }\end{array}$ & JENIS KASUS & TAHUN & KET. \\
\hline 1 & PT. PBB & Hubungan Industerial & 2004 & TUTUP \\
\hline 2 & PT. Foster Electric & Hubungan Industerial & 2004 & \\
\hline 3 & PT. MKPI & Hubungan Industerial & 2004 & TUTUP \\
\hline 4 & PT. TEC & Hubungan Industerial & 2004 & \\
\hline 5 & $\begin{array}{ll}\text { PT. } & \text { Sanipak } \\
\text { Indonesia } & \end{array}$ & Hubungan Industerial & 2005 & \\
\hline 6 & PT. Fujitec & Hubungan Industerial & 2005 & TUTUP \\
\hline 7 & PT. AIT & Hubungan Industerial & 2005 & \\
\hline 8 & PT. Sumitomo & Hubungan Industerial & 2005 & \\
\hline 9 & PT. Infineon & Hubungan Industerial & 2005 & \\
\hline 10 & PT Singatronic & Hubungan Industerial & 2006 & TUTUP \\
\hline 11 & PT Unisem & Hubungan Industerial & 2006 & \\
\hline 12 & PT Exas & Hubungan Industerial & 2007 & TUTUP \\
\hline 13 & PT BJ Industries & Hubungan Industerial & 2008 & TUTUP \\
\hline 14 & $\begin{array}{ll}\text { PT } & \text { Epson } \\
\text { Toyocom } & \\
\end{array}$ & Hubungan Industerial & 2008 & TUTUP \\
\hline 15 & PT Paper Box & Hubungan Industerial & 2009 & TUTUP \\
\hline 16 & PT ASAHI & $\begin{array}{l}\text { Internal/Hubungan } \\
\text { Industrial }\end{array}$ & 2009 & TUTUP \\
\hline 17 & PT Singacom & $\begin{array}{l}\text { Internal/Hubungan } \\
\text { Industrial }\end{array}$ & 2009 & TUTUP \\
\hline 18 & $\begin{array}{l}\text { PT Toyocom } \\
\text { Indonesia }\end{array}$ & $\begin{array}{l}\text { Internal/Hubungan } \\
\text { Industrial }\end{array}$ & 2010 & TUTUP \\
\hline 19 & PT Sony & $\begin{array}{l}\text { Internal/Hubungan } \\
\text { Industrial }\end{array}$ & 2010 & TUTUP \\
\hline 20 & $\begin{array}{l}\text { PT Kumagaya } \\
\text { Precision Motor } \\
\text { Batam }\end{array}$ & $\begin{array}{l}\text { Internal/Hubungan } \\
\text { Industerial }\end{array}$ & 2011 & TUTUP \\
\hline 21 & PT TEAC & Internal & 2011 & Relokasi \\
\hline 22 & $\begin{array}{ll}\text { PT } & \text { Panasonic } \\
\text { Battery } & \\
\end{array}$ & $\begin{array}{l}\text { Internal/Hubungan } \\
\text { Industerial }\end{array}$ & 2012 & TUTUP \\
\hline
\end{tabular}

31 Perselisihan Hubungan Industrial (PHI) adalah perbedaan pendapat yang mengakibatkan pertentangan antara pengusaha atau gabungan pengusaha dengan pekerja/buruh atau serikat pekerja/buruh karena adanya perselisihan mengenai hak, perselisihan kepentingan, perselisihan pemutusan hubungan kerja dan perselisihan antar serikat pekerja/serikat buruh dalam satu perusahaan (Ps. 1) Undang-undang No 2 Tahun 2004 Tentang Penyelesaian Hubungan Industrial. 


\begin{tabular}{|l|l|l|l|l|}
\hline 23 & PT Nutune & $\begin{array}{l}\text { Internal/Hubungan } \\
\text { Industerial }\end{array}$ & 2012 & TUTUP \\
\hline 24 & PT Kemet & $\begin{array}{l}\text { Internal/Hubungan } \\
\text { Industrial }\end{array}$ & 2012 & \\
\hline 25 & PT Nagano & Hubungan Industrial & 2012 & \\
\hline 26 & $\begin{array}{l}\text { PT Japan Servo } \\
\text { Batam }\end{array}$ & $\begin{array}{l}\text { Internal/Hubungan } \\
\text { Industrial }\end{array}$ & 2013 & TUTUP \\
\hline 27 & PT E-Tech & Hubungan Industrial & 2013 & TUTUP \\
\hline 28 & $\begin{array}{l}\text { PT NISSIN } \\
\text { KOGYO }\end{array}$ & Hubungan Industrial & 2013 & \\
\hline 29 & PT Foster Electric & Hubungan Industrial & 2014 & \\
\hline 30 & PT JMS Sanipak & Hubungan Industrial & 2014 & \\
\hline 31 & PT Siemen & Hubungan Industrial & 2015 & TUTUP \\
\hline 32 & PT Sanmina & Hubungan Industrial & 2015 & \\
\hline 33 & $\begin{array}{l}\text { PT Industrial } \\
\text { Indonesia }\end{array}$ & 2015 & \\
\hline 34 & PT Cicor Panatec & Hubungan Industrial & 2015 & \\
\hline
\end{tabular}

Tabel C.1

(Tabel diatas adalah gambaran Hubungan Industrial di Kawasan Industeri Batamindo dalam kurun waktu 2004-2015) ${ }^{32}$.

Ditambah dengan adanya hasil responden yang telah mengirimkan jawaban atas 15 belas pertanyaan diantara pertanyaan dan hasilnya adalah sebagai berikut :

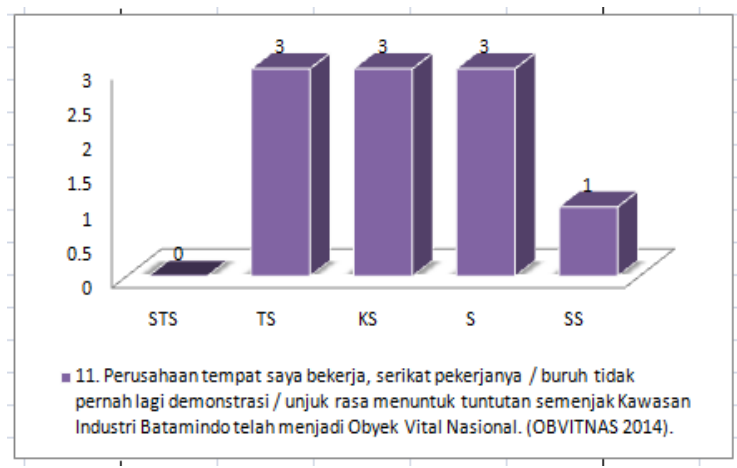

Gambar : E.1

${ }^{32}$.Data table disusun HR Manager pada pe pada dokumen IPSM

JOURNAL OF L

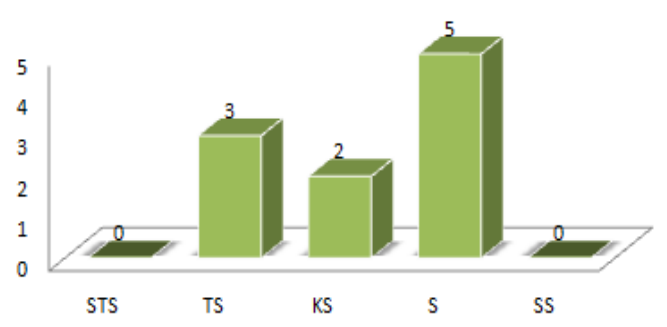

=12. Perusahaan tempat saya bekerja, serikat pekerjanya / buruh tidak pernah lagi dapat ajakan daemo oleh serikat pekerja / buruh perusahaan lain sejak Kawasan Industri Batamindo teleah menjadi Obyek Vital Nasional (OBVITNAS 2014). zrja di perusahaan sebagai lengan data yang diambil 


\section{Gambar : E.2}

Semenjak ditetapkan Obyek Vital Nasional Kawasan Industri Batamindo bukan beararti tidak adanya gangguan seperti unjuk rasa, dalam kenyataanya masih terjadi demontrasi dan unjuk rasa akibat permasalahan hubungan industrial (lihat gambar:C.1) sedangkan pekerja / buruh yang bekerja diperusahaan masih terjadi diajak untuk aksi solidaritas serikat pekerja/serikat buruh perusahaan lain dalam hal terjadi permasalahan hubungan industrial disuatu perusahaan (lihat gambar : C.2)

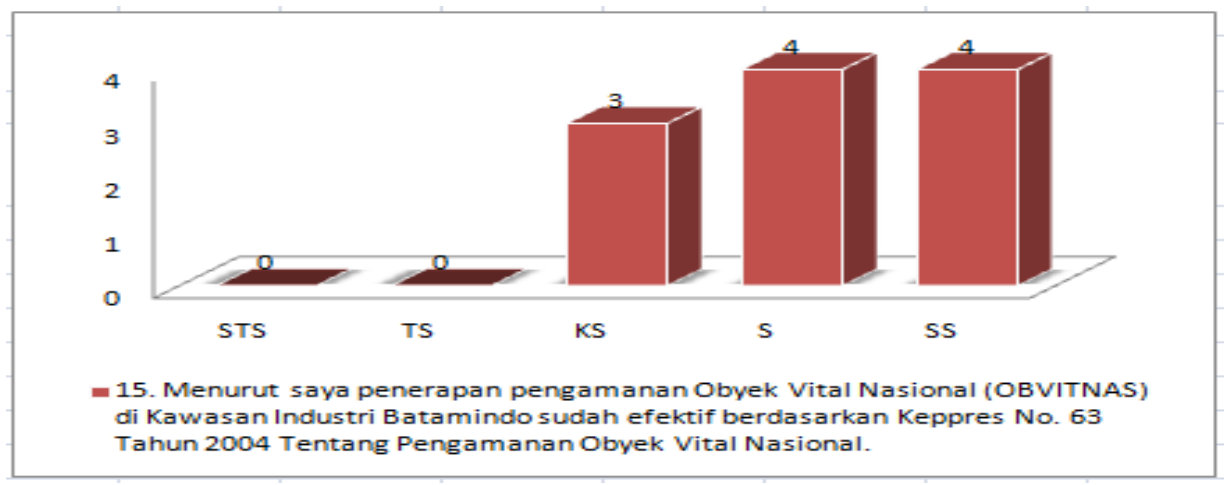

\section{Gambar : E.3}

Secara umum responden menyatakan bahwa Penerapan Keppres No. 63 Tahun 2004 Tentang Pengamanan Obyek Vital Nasional Di Kawasan Industri Batamindo telah berjalan efektif berdasarkan Keppres No. 63 Tahun 2004 Tentang Pengamanan Obyek Vital Nasioanl, walaupun masih ada yang kurang setuju (lihat gambar: C.3)Sebelum pembahasan berdasarkan teori yang peneliti gunakan yakni Teori Efektifitas Soejono Soekanto maka dapat dijelaskan gambaran umum gerakan serikat buruh di Kawasan Industeri Batamindo setelah Keppres No. 63 Tahun 2004, gerakan yang dimaksud adalah aksi Serikat Pekerja/Serikat Buruh dalam melakukan unjuk rasa, demontrasi dan juga mogok kerja yang dapat mengganggu keberlangsungan proses produksi tempat mereka bekerja, tidak hanya gerakan diatas menganggu proses produksi bahkan dapat mengakibatkan tutupnya perusahaan serta berpotensi dapat digunakan pihak kompititor pemodal Negara asing yang sengaja mengancam stabilitas politik dan ekonomi nasional, berikut adalah gambaran umum secara kuantitias ada 30 perusahaan yang peneliti dapatkan dari berbagai sumber dari para HR Manager yang dapat peneliti hubungi selaku saksi dan praktisi perjalanan hubungan industrial di Kawasan Industeri Batamindo ditambah data dari media massa, sebagaimana data pada table C.1 menggambarkan betapa gerakan aksi tersebut dapat menganggu adanya 
kelangsungan produksi dan juga tutupnya perusahan data tersebut dengan periode 2004 - 2014 sebeblum diterbitkannya Keppres 63, akan tetapi setelah diterbitkannya Keppres dan ditambah dengan telah didapatkannya status Obyek Vital Nasional Kawasan Industeri Batamindo maka hanya ada 4 perusahaan yang mengalami unjuk rasa dan demontrasi yakni PT. Sanmina dan PT Siemen, PT Cicor dan PT Sanipak dan dari 4 perusahaan diatas hanya 1 yang tutup yaitu PT Siemen.Setelah peneliti menyajikan data-data sebagaimana Tabel C 1 (Tabel diatas adalah gambaran Hubungan Industrial di Kawasan Industeri Batamindo dalam kurun waktu 2004-2015) dan ditambah dengan pendekatan berdasarkan teori Efektifitas Hukum Soerjono Soekanto diatas maka Peneliti menyimpulkan bahwa setelah pengusiran aksi unjuk rasa/demontrasi yang ditujukan kepada massa dari serikat SBSI yang akan menyampaikan pendapat dimuka umum di dalam Kawasan Industeri Batamindo yang direncanakan pada tanggal 10-12 Nopember 2016 ditambah dengan tidak ditemukan lagi aksi unjuk rasa, demontrasi juga mogok kerja masih ditambah lagi tidak ditemukannya penutupan jalan, pemblokiran pintu, sweeping masuk perusahaan apabila terjadi permasalahan hubungan industrial di perusahaan di Kawasan Industeri Batamindo, maka peneliti berkesimpulan indikasi diatas menjadi tolak ukur dalam KE-EFEKTIFAN Perapan Pengamanan Obyek Vital Nasional Berdasarkan Keppres No 63 Tahun 2004 Tentang Pengamanan Obyek Vital Nasional di Kawasan Industeri Batamindo. Hal ini dikuatkan data pembanding kasus permasalahan hubungan industrial dibawah yang tidak sampai terjadi adanya unjuk rasa atau demontrasi dan juga mogok di perusahaan. Sedangkan permasalahan hukum perselisihannya mengenai hubungan industrial yang terjadi tetap berjalan sesuai dengan ketentuan hukum ketenagakerjaan namun tidak dibarengi adanya aksi unjuk rasa, demontrasi apalagi sweeping hingga pemblokiran pintu yang dapat mengganggu keberlangsungan produksi, dibawah daftar Perusahaan yang berkasus permasalahan hubungan industrial kurun waktu 2015-2016 ${ }^{33}$ :

\section{B. Daftar Perusahaan yang mempunyai kasus hubungan Industrial ${ }^{34}$ tidak disertai unjuk rasa/demontrasi dan mogok kerja di Kawasan Industri Batamindo periode tahun 2015 - 2016}

\begin{tabular}{|c|l|c|c|}
\hline No & \multicolumn{1}{|c|}{ Nama Perusahaan } & Kasus & Tahun \\
\hline 1. & PT Varta Battery & $\begin{array}{c}\text { Hubungan } \\
\text { Industrial }\end{array}$ & 2016 \\
\hline 2. & PT Techwah Paper & $\begin{array}{c}\text { Hubungan } \\
\text { Industrial }\end{array}$ & 2016 \\
\hline 3. & PT JMS & $\begin{array}{c}\text { Hubungan } \\
\text { Industrial }\end{array}$ & 2016 \\
\hline
\end{tabular}

\footnotetext{
33. Daftar nama perusahaan serta kasus didapat dari dokumen IPSM - Kepri ( Ikatan Praktisi Sumber Daya Manusia) Kepri

34 . ibid,
} 
Tabel E. 2

\section{(Table diatas menunjukkan bahwa jenis kasus berkurang dan tidak disertai aksi unjuk rasa/ demontrasi serta mogok kerja) ${ }^{35}$.}

Peneliti berpandangan bahwa berdasarkan Tabel E.1 (Tabel diatas adalah gambaran Hubungan Industrial di Kawasan Industri Batamindo dalam kurun waktu 2004-2015) dan dibandingkan dengan Tabel E.2 (Table diatas menunjukkan bahwa jenis kasus berkurang dan tidak disertai aksi unjuk rasa/demontrasi serta mogok kerja) adalah sebagai TOLAK UKUR KE-EFEKTIFAN Penerapan Keppres No. 63 Tahun 2004 Tentang Pengamanan Obyek Vital Nasional Di Kawasan Industri Batamindo ditambah lagi dari hasil wawancara yang peneliti lakukan kepada Direktur LBH SPMI Kota Batam, Ketua Serikat Pekerja Seluruh Indonesia (KSPSI) Kota Batam, Ketua Divisi Hukum Korwil KSBSI Kepri, Koordinator IPSM - Kepri, Chief Security Operation PT BIC, Kabag Ops Ditpam Obvit Polda Kepri, Manager Admin \& General Affair PT BIC, Legal PT BIC, semuanya mengatakan telah efektif.

Dengan menggunakan Landasan Teori ( Teori Efektifitas Hukum) fungsi dimana dari teori dalam suatu penelitian adalah untuk memberikan pengarahan kepada penelitian yang dilakukan. Dalam menganalisis permasalahan yang dirumuskan, diperlukan beberapa teori yang relevan, dengan maksud supaya permasalahannya dapat dijelaskan secara memuaskan. Selanjutnya teori yang digunakan dalam penelitian ini adalah Teori Efektivitas Hukum Oleh Soerjono Soekanto, Penegakan hukum dalam bahasa belanda disebut dengan rechtstoepassing atau rechtshandhaving dan dalam bahasa inggris law enforcement. Hukum dan penegakan Hukum merupakan satu kesatuan yang tidak dapat dipisahkan, keduanya harus berjalan secara sinergis. Subtansi hukum yang termuat dalam berbagai peraturan perundang-undangan hanya akan menjadi sampah tanpa diiringi dengan sistem hukum serta budaya hukum yang tumbuh dan berkembang dalam masyarakat. Penegakan hukum merupakan bentuk nyata dalam melaksanakan hukum demi mewujudkan keadilan dan kepastian hukum yang dilaksanakan oleh struktur hukum yakni aparat penegak hukum terhadap materi atau substansi hukum itu sendiri bagi para pelanggar hukum. Penegakan hukum (law enforcement)dalam arti luas mencakup kegiatan untuk melaksanakan dan menerapkan hukum serta melakukan tindakan hukum terhadap setiap pelanggaran atau penyimpangan hukum yang dilakukan oleh subyek hukum, baik melalui prosedur peradilan maupun melalui abitrase dan mekanisme penyelesaian sengketa lainnya (Alternative dispute or conflicts resolution). ${ }^{36}$ Dalam pengertian yang lebih luas, kegiatan penegakan hukum mencakup pula segala aktivitas yang dimaksudkan agar hukum sebagai perangkat kaidah normatif yang mengatur dan mengikat pada subjek hukum dalam segala aspek kehidupan bermasyarakat dan bernegara benar-benar ditaati dan sungguh-sungguh dijalankan sebagaimana

\footnotetext{
35. Hasil wawancara dengan Sekjend IPSM - Kepri ( Ikatan Praktisi Sumber Daya Manusia) Kepri 7 September 2016.

36 . Jimly Asshidiqie, Menuju Negara Hukum yang Demokrasi, Jakarta:PT.Bhuana Ilmu Populer, 2009, Hal.22
} 
mestinya. Penegakan hukum dalam arti sempit menyangkut kegiatan penindakan terhadap setiap pelanggaran atau penyimpangan terhadap peraturan perundangundangan, khususnya melalui proses peradilan pidana yang melibatkan peran serta aparat kepolisian, kejaksaan, advokat atau pengacara dan badan-badan peradilan karena itu aktor-aktor utama yang peranannya sangat menonjol dalam proses penegakan hukum adalah polisi, jaksa, pengacara dan hakim ${ }^{37}$.Secara konsepsional, maka inti dan arti penegakan hukum terletak pada kegiatan menyelesaikan hubungan nilai-nilai yang terjabarkan di dalam kaidah kaidah yang mantap dan mengejawantahkan dan sikap tindak sebagai rangkaian penjabaran nilai tahap akhir, untuk menciptakan, memelihara dan mempertahankan kedamaian pergaulan hidup ${ }^{38}$. Selanjutnya menurut Soerjono Soekanto, menyebutkan bahwa masalah pokok dari efektivitas penegakan hukum sebenarnya terletak pada faktor-faktor yang mungkin memengaruhinya, yaitu: ${ }^{39}$ Faktor hukumnya sendiri yang berupa undangundang; dalam ini Hukum berfungsi untuk keadilan, kepastian dan kemanfaatan. Dalam praktik penyelenggaraan hukum di lapangan ada kalanya terjadi pertentangan antara kepastian hukum dan keadilan. Kepastian Hukum sifatnya konkret berwujud nyata, sedangkan keadilan bersifat abstrak sehingga ketika seorang hakim memutuskan suatu perkara secara penerapan undang-undang saja maka ada kalanya nilai keadilan itu tidak tercapai. Maka ketika melihat suatu permasalahan mengenai hukum setidaknya keadilan menjadi prioritas utama. Karena hukum tidaklah sematamata dilihat dari sudut hukum tertulis saja, masih banyak aturan-aturan yang hidup dalam masyarakat yang mampu mengatur kehidupan masyarakat. Jika hukum tujuannya hanya sekedar keadilan, maka kesulitannya karena keadilan itu bersifat subjektif, sangat tergantung pada nilai-nilai intrinsik subjektif dari masing-masing orang. Mengenai faktor hukum dalam hal ini dapat diambil contoh pada pasal 363 KUHP yang perumusan tindak pidananya hanya mencantumkan maksimumnya saja, yaitu 7 tahun penjara sehingga hakim untuk menentukan berat ringannya hukuman dimana ia dapat bergerak dalam batas-batas maksimal hukuman. Oleh karena itu, tidak menutup kemungkinan hakim dalam menjatuhkan pidana terhadap pelaku kejahatan itu terlalu ringan, atau terlalu mencolok perbedaan antara tuntutan dengan pemidanaan yang dijatuhkan. Hal ini merupakan suatu penghambat dalam penegakan hukum tersebut.

Kemudian Faktor penegak hukum Faktor ini meliputi pihak-pihak yang membentuk maupun menerapkan hukum atau law enforcement. Bagian-bagian law enforcement itu adalah aparatur penegak hukum yang mampu memberikan kepastian, keadilan, dan kemanfaat hukum secara proporsional. Aparatur penegak hukum mencakup pengertian mengenai institusi penegak hukum dan aparat (orangnya) penegak hukum, sedangkan aparat penegak hukum dalam arti sempit dimulai dari kepolisian, kejaksaan, kehakiman, penasehat hukum dan petugas sipir lembaga pemasyarakatan. Setiap aparat dan aparatur diberikan kewenangan dalam

\footnotetext{
37 .Ibid

38. Ibid

${ }^{39}$. Soerjono Soekanto, Faktor-Faktor yang Mempengaruhi Penegeakan Hukum, Jakarta: Raja Grafindo Persada, 2004, Hal.42
} 
melaksanakan tugasnya masing-masing, yang meliputi kegiatan penerimaan laporan, penyelidikan, penyidikan, penuntutan, pembuktian, penjatuhan vonis dan pemberian sanksi, serta upaya pembinaan kembali terpidana. Sistem peradilan pidana harus merupakan kesatuan terpadu dari usaha-usaha untuk menanggulangi kejahatan yang sesungguhnya terjadi dalam masyarakat. Apabila kita hanya memakai sebagian ukuran statistik kriminalitas, maka keberhasilan sistem peradilan pidana akan dinilai berdasarkan jumlah kejahatan yang sampai ke alat penegak hukum. Beberapa banyak yang dapat diselesaikan kepolisian, kemudian diajukan oleh kejaksaan ke pengadilan dan dalam pemeriksaan di pengadilan dinyatakan bersalah dan dihukum. Sebenarnya apa yang diketahui dan diselesaikan melalui sistem peradilan pidana hanya puncaknya saja dari suatu gunung es. Masih banyak yang tidak terlihat, tidak dilaporkan mungkin pula tidak diketahui, misalnya dalam hal "kejahatan dimana korbannya tidak dapat ditentukan atau "crimes without victims" dan karena itu tidak dapat di selesaikan. Keadaan seperti ini tidak dapat dipersalahkan sepenuhnya kepada sistem peradilan pidana. Karena tugas sistem ini terutama adalah menyelesaikan kasus-kasus yang sampai padanya. Secara sosiologis, setiap aparat penegak hukum tersebut mempunyai kedudukan (status) dan peranan (role). Kedudukan (sosial) merupakan posisi tertentu di dalam struktur kemasyarakatan. Kedudukan tersebut merupakan peranan atau role, oleh karena itu seseorang yang mempunyai kedudukan tertentu, lazimnya mempunyai peranan. Suatu hak merupakan wewenang untuk berbuat dan tidak berbuat, sedangkan kewajiban adalah beban atau tugas. Suatu peranan tertentu dapat di jabarkan dalam unsur- unsur sebagai berikut : (1) peranan yang ideal / ideal role; (2) peranan yang seharusnya / expected role; (3) peranan yang dianggap oleh diri sendiri / perceived role; dan (4) peranan yang sebenarnya dilakukan / actual role. Penegak hukum dalam menjalankan perannya tidak dapat berbuat sesuka hati mereka juga harus memperhatikan etika yang berlaku dalam lingkup profesinya, etika memperhatikan atau mempertimbangkan tingkah laku manusia dalam pengambilan keputusan moral. Dalam profesi penegak hukum sendiri mereka telah memiliki kode etik yang diatur tersendiri, tapi dalam prakteknya kode etik yang telah ditetapkan dan di sepakati itu masih banyak di langgar oleh para penegak hukum. Akibat perbuatan-perbuatan para penegak hukum yang tidak memiliki integritas bahkan dapat dikatakan tidak beretika dalam menjalankan profesinya, sehingga mengakibatkan lambatnya pembangunan hukum yang diharapkan oleh bangsa ini, bahkan menimbulkan pikiran-pikiran negative dan mengurangi kepercayaan masyarakat terhadap kinerja penegak hukum. Aturan para aparat dan aparatur penegak hukum dijabarkan sebagaimana berikut : a. Kepolisian, kekuasaan polisi/polri adalah merupakan sebagai perwujudan istilah yang menggambarkan penjelmaan tugas, status, organisasi,wewenang dan tanggung jawab polisi. Secara umum kedudukan, fungsi dan tugas kepolisian diatur dalam Undang-Undang Nomor 2 Tahun 2002 tentang Kepolisian RI. b. Kejaksaan, secara umum kedudukan, fungsi dan tugasnya diatur dalam undang-undang nomor 16 tahun 2004 tentang kejaksaan RI. c. Kehakiman, secara umum kedudukan, fungsi dan tugasnya diatur dalam undang-undang nomor 4 tahun 2004 tentang kekuasan hakim.d. Lembaga pemasyarakatan, secara umum kedudukan, fungsi dan tugasnya diatur dalam undang-undang nomor 19 tahun 2005 tentang pemasyarakatan. Ada tiga elemen penting yang mempengaruhi mekanisme bekerjanya aparat dan aparatur penegak 
hukum, menurut Jimmly Asshidiqie elemen tersebut antara lain: (1) istitusi penegak hukum beserta berbagai perangkat sarana dan prasarana pendukung dan mekanisme kerja kelembagaannya; (2) budaya kerja yang terkait dengan aparatnya, termasuk mengenai kesejahteraan aparatnya; dan (3) perangkat peraturan yang mendukung baik kinerja kelembagaanya maupun yang mengatur materi hukum yang dijadikan standar kerja, baik hukum materilnya maupun hukum acaranya. Upaya penegakan hukum secara sistematik haruslah memperhatikan ketiga aspek itu secara simultan, sehingga proses penegakan hukum dan keadilan secara internal dapat diwujudkan secara nyata. Dalam pelaksanaannya penegakan hukum oleh penegak hukum di atas dijumpai beberapa halangan yang disebabkan oleh penegak hukum itu sendiri, halanganhalangan tersebut antara lain: 1. Keterbatasan kemampuan untuk menempatkan diri dalam peranan pihak lain dengan siapa dia beriteraksi. 2.Tingkat aspirasi yang relative belum tinggi.3.Kegairahan yang sangat terbatas untuk memikirkan masa depan, sehingga sulit sekali untuk membuat suatu proyeksi. 4.elum adanya kemampuan untuk menunda pemuasan suatu kebutuhan tertentu, terutama kebutuhan materiel. 5. Kurangnya daya inovatif yang sebenarnya merupakan pasangan konservatisme. Menurut Soerjono Soekanto hambatan maupun halangan penegak hukum dalam melakukan penegakan hukum tersebut dapat diatasi dengan cara mendidik, membiasakan diri untuk mempunyai sikap-sikap antara lain: sikap terbuka, senantiasa siap menerima perubahan, peka terhadap masalah yang terjadi, senantiasa mempunyai informasi yang lengkap, orientasi ke masa kini dan masa depan, menyadari potensi yang dapat di kembangkan, berpegang pada suatu perencanaan, percaya pada kemampuan iptek, menyadari dan menghormati hak dan kewajiban, berpegang teguh pada keputusan yang diambil atas dasar penalaran dan perhitungan yang mantab. Penerapan Keppres No. 63 Tahun 2004 tentang Pengamanan Obyek Vital Nasional di Kawasan Industri Batamindo, menurut peneliti sebagaimana diketahui penerbitan Keppres tersebut tidak muncul begitu saja akan tetapi berdasarkan tinjauan dari sisi yuridis juga historis sehingga memunculkan sebuah konsep. Undang Undang Dasar Negara Republik Indonesia atau disingkat UUD 1945 atau UUD'45, adalah hukum dasar tertulis (basic law), konstitusi pemerintahan negara Republik Indonesia saat ini UUD 1945 disahkan sebagai undang-undang dasar negara oleh PPKI pada tanggal 18 Agustus 1945. UUD 1945telah mengalami 4 kali perubahan (amendemen), yang mengubah susunan lembaga-lembaga dalam sistem ketatanegaraan Republik Indonesia didalam Pasal 28 ayat (3) dinyatakan "setiap orang berhak atas kebebasan berserikat, berkumpul dan mengeluarkan pendapat " kemudian pada Pasal (4) dinyatakan "Kepolisian Negara Republik Indonesia sebagai alat Negara yang menjaga keamanan dan ketertiban masyarakat bertugas melindungi, mengayomi melayani masyarakat, serta menegakkan hukum.

Setelah diamandemennya UUD 1945 terdapat perubahan terhadap alat pertahanan Negara yang mencerminkan urusan keamanan masyarakat diberikan wewenang kepada POLRI dan menyangkut keamanan negara diberikan wewenang kepada TNI berikut adalah Undang-Undang No 2 tahun 2014 tentang Kepolisian Negara Republik Indonesia, BAB I tentang KETENTUAN UMUM pada Pasal (2) dinyatakan" Fungsi kepolisian adalah salah satu fungsi pemerintahan negara di bidang 
pemeliharaan dan ketertiban masyarakat, penegakan hukum, perlindungan, pengayoman pelayanan kepada masyarakat", kemudian Pasal (4) dinyatakan" Kepolisian Negara Republik Indonesia bertujuan untuk mewujudkan keamanan dalam negeri yang meliputi terpeliharanya perlindungan, pengayoman, dan pelayanan kepada masyarakat, serta terbinanya ketenteraman masyarakat dengan menjunjung tinggi hak asasi manusia". Kemudian pada Pasal (5) ayat 3 dinyatakan "Kepolisian Negara Republik Indonesia merupakan alat negara yang berperan dalam memelihara keamanan dan ketertiban masyarakat, menegakkan hukum, serta memberikan perlindungan, pengayoman, dan pelayanan kepada masyarakat dalam rangka terpeliharanya keamanan dalam negeri". dilanjutkan pada ayat 4 dinyatakan "Kepolisian Negara Republik Indonesia adalah Kepolisian Nasional yang merupakan satu kesatuan dalam melaksanakan peran sebagaimana dimaksud dalam ayat (1)".

Produk hukum dari masa pemerintahan Orde Baru sangat tidak mungkin untuk dapat menjamin atau memberikan perlindungan terhadap Hak-hak Asasi Manusia (HAM), berkembangnya demokrasi serta munculnya kreativitas masyarakat ${ }^{40}$. Dengan semangat reformasi Undang - Undang Republik Indonesia Nomor 9 Tahun 1998 Tentang Kemerdekaan Menyampaikan Pendapat di Muka Umum, Pada pasal (9) ayat 1 dinyatakan "Bentuk penyampaian pendapat di muka umum dapat dilaksanakan dengan: a. unjuk rasa atau dernonstrasi; b. pawai; c. rapat umum; dan atau d. mimbar bebas". Kemudian pada Pasal (2) dinyatakan " Penyampaian pendapat di muka umum sebagaimana dimaksud dalam ayat (1). dilaksanakan di tempat-tempat terbuka untuk umum. kecuali : a. di lingkungan istana kepresidenan, tempat ibadah. instalasi militer, rumah sakit, pelabuhan udara atau laut, stasiun kereta api, terminal angkutan darat, dan obyek-obyek vital nasional; b. pada hari besar nasional". dan ayat 3 dinyatakan "Pelaku atau peserta penyampaian pendapat di muka umum sebagaimana dimaksud dalam ayat (1) dilarang membawa benda-benda yang dapat membahayakan keselamatan umum". ada penegasan dalam hal mengatur menyampaikan pendapat di muka umum sebagaimana tercantum pada Pasal (15) yang dinyatakan " Pelaksanaan penyampaian pendapat di muka umum dapat dibubarkan apabila tidak mcmenuhi ketentuan sebagaimana dimaksud dalam Pasal 6, Pasal 9 ayat (2) dan ayat (3), Pasal 10, dan Pasal 11".

Terkait dengan kandungan pada Keppres No 63 Tahun 2004 Tentang Pengamanan Obyek Vital Nasional merupakan sebuah payung hukum POLRI dalam memberikan pengamanan terhadap Obyek Vital yang telah disyahkan secara legalitas oleh Kementrian terkait, POLRI tentu tidak cukup dengan Undang-Undang Nomor 2 Tahun 2014 tentang Kepolisian Negara Republik Indonesia yang bersifat umum, Keppres tersebut merupakan arah yang konkrit diberikan POLRI untuk melakukan pengamanan pada Obyek Vital Nasional. Sedangkan keterkaitanya dengan kebebasan menyampaikan pendapat dimuka umum maka diberikannya rambu-rambu pada

\footnotetext{
40 . Brata Trisnu Nugroho.2006. Prahara Reformasi Mei 1998.semarang:UPT UNNES Press,2006.
} 
tempatnya yakni sesuai dengan Pasal (2) ayat 1 huruf (a ) Undang-undang Nomor 9 Tahun 1998 Tentang Kemerdekaan Menyampaikan Pendapat di Muka Umum, kecuali " a. di lingkungan istana kepresidenan, tempat ibadah. instalasi militer, rumah sakit, pelabuhan udara atau laut, stasiun kereta api. terminal angkutan darat, dan obyekobyek vital nasional".

Terkait dengan Teori Efektifitas Sorjono Soekanto mengenai Undangundangnya sendiri dalam hal ini berupa Keppres Nomor 63 Tahun 2004 Tentang Pengamanan Obyek Vital Nasional dapat penulis sampaikan telah memenuhi dan sesuai dengan kondisi sosiologi yang ada, yaitu hukum mengikuti dengan perkembangan zaman yang berlaku dan hal ini juga berdasarkan indikator - indikator telah menunjukkan, mengarah kepada efektifnya Penerapan Keppres No. 63 Tahun 2004 Tentang Pengamanan Obyek Vital Nasional Di Kawasan Industri Batamindo di Kawasan Industri Batamindo terlihat dari indikator-indikator para narasumber yang peneliti wawancara dari mulai Pengurus Serikat, Pengurus Praktisi Para HR atau Personalia, Pengelola Kawasan Industri Batamindo, Kepolisian serta ditambah hasil dari survey berupa kuesioner menunjukkan ke arah efektif Selanjutnya Faktor sarana atau fasilitas yang mendukung penegakan hukum, Fasilitas pendukung secara sederhana dapat dirumuskan sebagai sarana untuk mencapai tujuan. Ruang lingkupnya terutama adalah sarana fisik yang berfungsi sebagai faktor pendukung. Fasilitas pendukung mencangkup tenaga manusia yang berpendidikan dan terampil, organisasi yang baik, peralatan yang memadai, keuangan yang cukup dan sebagainya. Jika fasilitas pendukung tidak terpenuhi maka mustahil penegakan hukum akan nencapai tujuannya. Kepastian dan kecepatan penyelesaian perkara tergantung pada fasilitas pendukung yang ada dalam bidang-bidang pencegahan dan pemberantasan kejahatan. Peningkatan tehnologi deteksi kriminalitas, mempunyai peranan yang sangat penting bagi kepastian dan penanganan perkara-perkara pidana, sehingga tanpa adanya sarana atau fasilitas tersebut tidak akan mungkin penegak hukum menyerasikan peranan yang seharusnya dengan peranan yang aktual, maka untuk sarana atau fasilitas tersebut sebaiknya dilakukan dengan cara sebagai berikut : 1 . yang tidak ada maka diadakan yang baru betul; 2. yang rusak atau salah maka diperbaiki atau di betulkan; 3. yang kurang seharusnya di tambah; 4. yang macet harus di lancarkan 5. yang mundur atau merosot harus di majukan atau di tingkatkan. Faktor ketiga yaitu faktor sarana atau fasilitas yang membantu penegakan hukum, menurut Soerjono Soekanto sendiri menyatakan bahwa tidak mungkin penegakan hukum akan berlangsung dengan lancar tanpa adanya sarana atau fasilitas yang memadai. Fasilitas atau sarana yang memadai tersebut, antara lain, mencakup tenaga manusia yang berpendidikan dan terampil, organisasi yang baik, peralatan yang memadai, keuangan yang cukup, dan seterusnya. Kalau hal itu tidak terpenuhi maka mustahil penegakan hukum akan mencapai tujuannya. Kita bisa bayangkan bagaimana penegakan peraturan akan berjalan sementara aparat penegaknya memiliki pendidikan yang tidak memadai, memiliki tata kelola organisasi yang buruk, di tambah dengan keuangan yang minim. Akan tetapi hal itu bukanlah segala-galanya kalau aparatnya sendiri masih buruk, karena sebaik apapun sarana atau fasilitas yang membantu penegakkan 
hukum tanpa adanya aparat penegak hukum yang baik hal itu hanya akan terasa siasia.

Faktor masyarakat, Penegakan hukum berasal dari masyarakat dan bertujuan untuk mencapai kedamaian didalam masyarakat. Masyarakat mempunyai pendapatpendapat tertentu mengenai hukum. Masyarakat Indonesia mempunyai pendapat mengenai hukum sangat berfareasi antara lain: 1. Hukum diartikan sebagai ilmu pengetahuan. 2. Hukum diartikan sebagai disiplin, yakni system ajaran tentang kenyataan; 3. Hukum diartikan sebagai norma atau kaidah, yakni patokan perilaku pantas yang diharapkan; 4. Hukum diartikan sebagai tata hukum (yakni hukum postitif tertulis); a. Hukum diartikan sebagai petugas atau pejabat; b. Hukum diartikan sebagai keputusan pejabat atau penguasa ; c. Hukum diartikan sebagai proses pemerintahan; d. Hukum diartikan sebagai perilaku teratur dan unik; e. Hukum diartikan sebagai jalinan nilai; f. Hukum diartikan sebagai seni. Berbagai pengertian tersebut di atas timbul karena masyarakat hidup dalam konteks yang berbeda, sehingga yang seharusnya dikedepankan adalah keserasiannya, hal ini bertujuan supaya ada titik tolak yang sama. Masyarakat juga mempunyai kecenderungan yang besar untuk mengartikan hukum dan bahkan mengindentifikasi dengan petugas (dalam hal ini adalah penegak hukum adalah sebagai pribadi). Salah satu akibatnya adalah bahwa baik buruknya hukum senantiasa dikaitkan dengan pola perilaku penegak hukum itu sendiri yang merupakan pendapatnya sebagai cerminan dari hukum sebagai struktur dan proses. Keadaan tersebut juga dapat memberikan pengaruh baik, yakni bahwa penegak hukum akan merasa perilakunya senantiasa mendapat perhatian dari masyarakat. Permasalahan lain yang timbul sebagai akibat anggapan masyarakat adalah mengenai penerapan undang-undangan yang ada / berlaku. Jika penegak hukum menyadari dirinya dianggap hukum oleh masyarakat, maka kemungkinan penafsiran mengenai pengertian perundang-undangan bisa terlalu luas atau bahkan terlalu sempit. Selain itu mungkin timbul kebiasaan untuk kurang menelaah bahwa perundang-undangan kadangkala tertinggal dengan perkembagan di dalam masyarakat. Anggapan-anggapan masyarakat tersebut harus mengalami perubahan dalam kadar tertentu. Perubahan tersebut dapat dilakukan melalui penerangan atau penyuluhan hukum yang berkesinambungan dan senantiasa dievaluasi hasil-hasinya, untuk kemudian dikembangkan lagi. Kegiatan-kegiatan tersebut nantinya akan dapat menempatkan hukum pada kedudukan dan peranan yang semestinya. Dengan melihat data berupa wawancara dan observasi juga kuiesioner peneliti berpendapat bahwa penegak hukum sudah mengarah pada efektif walaupun masih perlu ditingkatkan lagi, dan masih diperlukan kerjasama antar lintas sektoral agar tidak terpengaruh pada figure pemimpin, artinya siapapun yang memimpin baik dari tingkat pusat mulai dari Presiden, Kapolri,Kapolda, Kapolres bahkan Kapolsek sekalipun tidak mempengaruhi system penindakan hukum sesuai dengan protab yang telah disepakati.

Sejalan Teori Soerjono Soekanto tentang Faktor penegak hukum, yakni pihak-pihak yang membentuk maupun menerapkan hukum masih relevan untuk dapat digunakan dasar menganalisi permasalah diatas.

Faktor kebudayaan, Faktor kebudayaan sebenarnya bersatu padu dengan faktor masyarakat sengaja dibedakan, karena didalam pembahasannya diketengahkan 
masalah sistem nilai-nilai yang menjadi inti dari kebudayaan spiritual atau non material. Hal ini dibedakan sebab menurut Lawrence M. Friedman yang dikutip Soerdjono Soekanto, bahwa sebagai suatu sistem (atau subsistem dari sistem kemasyarakatan), maka hukum menyangkup, struktur, subtansi dan kebudayaan. Struktur menyangkup wadah atau bentuk dari sistem tersebut yang, umpamanya, menyangkup tatanan lembaga-lembaga hukum formal, hukum antara lembagalembaga tersebut, hak-hak dan kewajiban-kewajibanya, dan seterusnya. Kebudayaan (sistem) hukum pada dasarnya mencangkup nilai-nilai yang mendasari hukum yang berlaku, nilai-nilai yang merupakan konsepsi-konsepsi abstrak mengenai apa yang dianggap baik (hingga dianuti) dan apa yang diangap buruk (sehingga dihindari). Nilai-nilai tersebut, lazimnya merupakan pasangan nilai-nilai yang mencerminkan dua keadaan estrim yang harus diserasikan. Pasangan nilai yang berperan dalam hukum menurut Soerdjono Soekanto adalah sebagai berikut :1. Nilai ketertiban dan nilai ketenteraman.2. Nilai jasmaniah/kebendaan dan nilai rohaniah/seakhlakan.3. Nilai kelanggengan/konservatisme dan nilai kebaruan/ inovatisme. Dengan adanya keserasian nilai dengan kebudayaan masyarakat setempat diharapkan terjalin hubungan timbal balik antara hukum adap dan hukum positif di Indonesia, dengan demikian ketentuan dalam pasal-pasal hukum tertulis dapat mencerminkan nilai-nilai yang menjadi dasar dari hukum adat supaya hukum perundang-undangan tersebut dapat berlaku secara efektif. Kemudian diharapkan juga adanya keserasian antar kedua nilai tersebut akan menempatkan hukum pada tempatnya. Pada elemen pertama Menurut Soerjono Seokanto ${ }^{41}$ ukuran efektivitas adalah

1. Peraturan yang ada mengenai bidang-bidang kehidupan tertentu sudah cukup sistematis.

2. Peraturan yang ada mengenai bidang-bidang kehidupan tertentu sudah cukup sinkron, secara hierarki dan horizontal tidak ada pertentangan.

3. Secara kualitatif dan kuantitatif peraturan-peraturan yang mengatur bidang-bidang kehidupan tertentu sudah mencukupi.

4. Penerbitan peraturan-peraturan tertentu sudah sesuai dengan persyaratan yuridis yang ada. Pada elemen kedua yang menentukan efektif atau tidaknya kinerja hukum tertulis adalah aparat penegak hukum. Dalam hubungan ini dikehendaki adanya aparatur yang handal sehingga aparat tersebut dapat melakukan tugasnya dengan baik. Kehandalan dalam kaitannya disini adalah meliputi keterampilan professional dan mempunyai mental yang baik. Menurut Soerjono Soekanto ${ }^{42}$ bahwa masalah yang berpengaruh terhadap efektivitas hukum tertulis ditinjau dari segi aparat akan tergantung pada hal berikut

1. Sampai sejauh mana petugas terikat oleh peraturan-peraturan yang ada

2. Sampai batas mana petugas diperkenankan memberikan kebijaksanaan.

3. Teladan macam apa yang sebaiknya diberikan oleh petugas kepada masyarakat.

4. Sampai sejauh mana derajat sinkronisasi penugasan-penugasan yang diberikan kepada petugas sehingga memberikan batas-batas yang tegas pada wewenangnya. Pada elemen ketiga, tersedianya fasilitas yang berwujud sarana dan prasarana bagi

41. Soerjono Soekanto, Penegakan Hukum, Bandung: Bina Cipta, 1980.

42 . Ibid, hal: 82 
aparat pelaksana didalam melakukan tugasnya. Sarana dan prasarana yang dimakud adalah prasarana atau fasilitas yang digunakan sebagai alat untuk mencapai efektivitas hukum. Sehubungan dengan sarana dan prasarana yang dikatakan dengan istilah fasilitas ini, Seoejono Soekanto ${ }^{43}$ memprediksi patokan efektivitas elemen-elemen tertentu dari prasarana, dimana prasaaran tersebut harus secara jelas memang menjadi bagian yang memberikan kontribusi iuntuk kelancaran tugas-tugas aparat di tempat atau lokasi kerjanya. Adapun elemen-elemen tersebut adalah :

1. Prasarana yang telah ada apakah telah terpelihara dengan baik.

2. Prasarana yang belum ada perlu diadakan dengan memperhitungkan angka waktu pengadaannya.

3. Prasarana yang kurang perlu segera dilengkapi.

4. Prasarana yang rusak perlu segera diperbaiki.

5. Prasarana yang macet perlu segera dilancarkan fungsinya.

6. Prasarana yang mengalami kemunduran fungsi perlu ditingkatkan lagi fungsinya. Kemudian ada beberapa elemen pengukur efektivitas yang tergantung dari kondisi masyarakat, yaitu : a. Faktor penyebab masyarakat tidak mematuhi aturan walaupun peraturan yang baik. b. Faktor penyebab masyarakat tidak mematuhi peraturann walaupun peraturan sangat baik dan aparat sudah sangat berwibawa. c. Faktor penyebab masyarakat tidak mematuhi peraturan baik, petugas atau aparat berwibawa serta fasilitas mencukupi. Elemen tersebut diatas memberikan pemahaman bahwa disiplin dan kepatuhan masayarakat tergantung dari motivasi yang secara internal muncul. Internalisasi faktor ini pada tiap individu yang menjadi elemen terkecil dari komunitas sosial. Oleh karena itu pendekatan paling tepat dalam hubungan disiplin ini adalah melalui motivasi yang ditanamkan secara individual. Dalam hal ini, derajat kepatuhan hukum masyarakat menjadi salah satu parameter tentang efektif atau tidaknya hukum itu diberlakukan sedangkan kepatuhan masyarakat tersebut dapat dimotivasi oleh berbagai penyebab, baik yang ditimbulkan oleh kondisi internal maupun eksternal. Kondisi internal muncul karena ada dorongan tertentu baik yang bersifat positif maupun negative. Dorongan positif dapat muncul karena adanya rangsangan yang positif yang menyebabkan seseorang tergerak untuk melakukan sesuatu yang bersifat positif. Sedangkan yang bersifat negative dapat muncul karena adanya rangsangan yang sifatnya negative seperti perlakuan tidak adil dan sebagainya. Sedangkan dorongan yang sifatnya eksternal karena adanya semacam tekanan dari luar yang mengharuskan atau bersifat memaksa agar warga masyarakat tunduk kepada hukum. Pada takaran umum, keharusan warga masyarakat untuk tunduk dan menaati hukum disebabkan karena adanya sanksi atau punishment yang menimbulkan rasa takut atau tidak nyaman sehingga lebih memilih taat hukum daripada melakukan pelanggaran yang pada gilirannya dapat menyusahkan mereka. Motivasi ini biasanya bersifat sementara atau hanya temporer. Teori efketivitas hukum yang dikemukakan Soerjono Soekanto tersebut relevan dengan teori yang dikemukakank oleh Romli Atmasasmita $^{44}$ yaitu bahwa faktor-faktor yang menghambat efektivitas penegakan

\footnotetext{
43 . Ibid, hal: 82

44 . Romli Atmasasmita, Reformasi Hukum, Hak Asasi Manuasia \& Penegakan Hukum, Bandung: Mandar Manju, 2001
} 
hukum tidak hanya terletak pada sikap mental aparatur penegak hukum (hakim, jaksa, polisi dan penasihat hukum) akan tetapi juga terletak pada faktor sosialisai hukum yang sering diabaikan.

Menurut Soerjono Seokanto ${ }^{45}$ efektif adalah taraf sejauh mana suatu kelompok dapat mencapai tujuannya. Hukum dapat dikatakan efektif jika terdapat dampak hukum yang positif, pada saat itu hukum mencapai sasarannya dalam membimbing ataupun merubah perilaku manusia sehingga menjadi perilaku hukum. Sehubungan dengan persoalan efektivitas hukum, pengidentikkan hukum tidak hanya dengan unsur paksaan eksternal namun juga dengan proses pengadilan. Ancaman paksaan pun merupakan unsur yang mutlak ada agar suatu kaidah dapat dikategorikan sebagai hukum, maka tentu saja unsur paksaan inipun erat kaitannya dengan efektif atau tidaknya suatu kententuan atau aturan hukum. Jika suatu aturan hukum tidak efektif, salah satu pertanyaan yang dapat muncul adalah apa yang terjadi dengan ancaman paksaanya? Mungkin tidak efektifnya hukum karena ancaman paksaanya kurang berat, mungkin juga karena ancaman paksaan itu tidak terkomunikasi secara memadai pada warga masyarakat ${ }^{46}$. Membicarakan tentang efektivitas hukum berarti membicarakan daya kerja hukum itu dalam mengatur dan atau memaksa masyarakat untuk taat terhadap hukum. Hukum dapat efektif jikalau faktor-faktor yang mempengaruhi hukum tersebut dapat berfungsi dengan sebaik-baiknkya. Ukuran efektif atau tidaknya suatu peraturan perundang-undangan yang berlaku dapat dilihat dari perilaku masyarakat. Suatu hukum atau peraturan perudang-undangan akan efektif apabila warga masyarakat berperilaku sesuai dengan yang diharapkan atau dikehendaki, maka efektivitas hukum atau peraturan perundang-undangan tersebut telah dicapai.

\section{E. Kesimpulan}

1. Penerapan Keppres No. 63 Tahun 2004 Tentang Pengamanan Obyek Vital Nasional Di Kawasan Industri Batamindo menjadi penting dan strategis melihat gangguan dan acamannya dapat mengganggu stabilitas ekonomi, sosial dan politik Nasional, karena didalamnya terdiri dari 68 perusahaan asing dari berbagai negara di dunia sehingga apabila terjadi masalah maka akan sangat cepat negara asal mengetahui dan merasakan dampaknya, disamping ada 46 ribu karyawan yang mengail rizki didalamnya masih ditambah dengan para supplier, pengusaha kecil menengah maka bisa jadi jumlahnya lebih dari 50 ribu orang, belum lagi bila dijumlahkan $2 \mathrm{x}$ lipat (karena setiap 1 orang biasanya menghidupi 2 orang dibelakangnya apakah ibu,bapak atau saudara) karena itu payung hukum seperti Keppres No.63 Tahun 2004 Tentang Pengamanan Obyek Vital Nasional sudah tepat agar kelangsungan investasi di Kawasan Industri Batamindo terdapat kepastian hukum apabila ada gangguan yang dapat mengancam tutupnya perusahaan atau terhambatnya proses produksi, sejalan dengan Teori Efektifitas bahwa pada pelaksanaannya penegakan hukum sebagaimana teori yang dikemukakan oleh Soerjono Soekanto bahwa faktor yang mempengaruhi penegakan hukum meliputi hukumnya sendiri, penegak

45. Soerjono Soekanto, Efektivitas Hukum dan Penerapan Sanksi, Bandung: CV. Ramadja Karya, 1988.

46. Achmad Ali, Menjelajahi Kajian Empiris Terhadap Hukum, Jakarta: Yarsif Watampone, 1988. 
hukum, sarana atau fasilitas, masyarakat, kebudayaan cenderung menuju efektif, sehingga kepastian hukum akan dapat menjadikan para investor dan masyarakat didalamnya aman dan nyaman.

2. Penerapan Keppres No. 63 Tahun 2004 Tentang Pengamanan Obyek Vital Nasional Di Kawasan Industri Batamindo sudah cenderung mengarah pada efektifnya Penerapan payung hukumnya yakni Keppres No. 63 Tahun 2004 Tentang Pengamanan Obyek Vital Nasional namun bukan berarti tidak ada kendala, kebiasaan di masyarakat hukum tergantung pada siapa yang menjadi pemimpinnya, agar penerapan pengamanan Obyek Vital Nasional di Kawasan Industri Batamindo tetap efektif dan lebih efektif diperlukan singkronisasi, komunikasi, koordinasi lintas sektoral agar payung hukum tentang Obyek Vital Nasional dapat tetap berjalan dengan efektif, tidak menutup mata bahwa Persoalan Hubungan Industrial yang dinamis akan dapat berpotensi terjadinya hambatan.

3. Sosialisai berkesinambungan mengenai Penerapan Keppres No. 63 Tahun 2004 Tentang Pengamanan Obyek Vital Nasional Di Kawasan Industri Batamindo kepada para stakeholder harus dilakukan dengan terencana dan sistematis agar mereka memahami sesuai dengan ketentuan hukum yang diharapkan disamping dengan peningkatan SDM satuan pengamanan itu sendiri juga harus ditingkatkan skill, pengetahuan serta nilai-nilai norma di masyarakat Kawasan Industri Batamindo seiring dengan tumbuh dan berkembangnya tehnology serta persaingan yang ketat dalam bidang ekonomi global saat ini. 


\section{DAFTAR PUSTAKA}

\section{Buku}

Achmad Ali, Menjelajahi Kajian Empiris Terhadap Hukum, Jakarta: Yarsif Watampone, 1988.

Amiruddin, Pengantar Metode Penelitian Hukum, Jakarta: PT Raja Grafindo Persada, 2012.

Bambang Sutiyoso, Metode Penemuan Hukum, Upaya Mewujudkan Hukum Yang Pasti dan Berkeadilan, Yogyakarta: UII Press, 2006.

Jimly Asshidiqie, Menuju Negara Hukum yang Demokrasi, Jakarta : PT Bhuana Ilmu Populer, 2009.

Joko Subagyo.P, Metode Penelitian Dalam Teori dan Praktek, Jakarta: Rineka Cipta, 1997.

Romli Atmasasmita, Reformasi Hukum, Hak Asasi Manusia \& Penegakan Hukum, Bandung: Mandar Maju, 2001.

Rina S. Shahrullah, Penelitian Kualitatif, Bahan Kuliah Metodologi Penelitian Hukum, Magister Hukum UIB,2015

Soerjono Soekanto, Efektivitas Hukum dan Penerapan Sanksi, Bandung: CV Ramadja Karya, 1988.

Faktor faktor yang mempengaruhi Penegakan Hukum, Jakarta: PT Raja Grafindo Persada, 2004

Pengantar Penelitian Hukum, Jakarta: PT. Raja Grafindo Persada

\section{Artikel}

Chief Security Operation PT BIC, Standard Operational Prosedur Pengamanan di Kawasan OBVITNAS di Kawasan Industri Batamindo Muka Kuning

\section{Website}


Wikipedia, Awaloedin Djamin tokoh Kepolisian Republik Indonesia, https://id.wikipedia.org

\section{Peraturan Perundang - Undangan}

Undang Undang Dasar Negara Republik Indonesia Tahun 1945

Undang Undang No. 2 Tahun 2014 Tentang Kepolisian Negara Republik Indonesia

Undang Undang Republik Indonesia No.3 Tahun 2013 Tentang Ketenagakerjaan

Undang Undang Republik Indonesia No. 2 Tahun 2004 Tentang Penyelesaian Perselisihan Hubungan Industrial

Undang Undang Republik Indonesia No.9 Tahun 1998 Tentang Kemerdekaan Menyampaikan Pendapat dimuka umum

Keppres No 63 tahun 2014 tentang Pengamanan Objek Vital Nasional 2012. 